\title{
Assessing the sensory characteristics and consumer preferences of yam-cowpea-soybean porridge in the Accra Metropolitan Area
}

\author{
Charles Tortoe*, Paa Toah Akonor, Stephen Nketia, Margaret Owusu, Mary Glover-Amengor, \\ Lynda Hagan, Alice Padi
}

Council for Scientific and Industrial Research, Food Research Institute, P. O. Box M20, Accra, Ghana

Email address:

ctortoe@yahoo.co.uk(C. Tortoe)

To cite this article:

Charles Tortoe, Paa Toah Akonor, Stephen Nketia, Margaret Owusu, Mary Glover-Amengor, Lynda Hagan, Alice Padi. Assessing the Sensory Characteristics and Consumer Preferences of Yam-Cowpea-Soybean Porridge in the Accra Metropolitan Area. International Journal of Nutrition and Food Sciences. Vol. 3, No. 2, 2014, pp. 127-132. doi: 10.11648/j.jinfs.20140302.27

\begin{abstract}
The objective of this study was to evaluate the sensory properties of porridge made from newly developed yam-legume flour blends and to determine preference among consumers. Thick porridge was prepared from 10 different yam-soybean-cowpea composite flours formulated using mixture design. Sensory evaluation employed 25-man panel to assess colour, aroma, mouthfeel, taste and overall acceptability of the 10 different porridge formulae on a 7-point Hedonic scale. Two highly ranked porridge formulations from the sensory evaluation were adopted for the consumer preference test involving 69 consumers. Sensory evaluation showed no significant difference $(p>0.05)$ between different formulations for all sensory attributes but only taste influenced the overall acceptability. Preparations with a combination of high amounts of yam flour and low levels of cowpea-soybean flour $(8: 1: 1 ; 5.5: 1: 1)$ were ranked highest. Consumer preference survey showed a general preference for porridge formulation with the highest amount of yam flour (8:1:1), with taste, mouthfeel and appearance being the highest attributes selected by consumers.
\end{abstract}

Keywords: Porridge, Yam-Cowpea-Soybean Flour, Sensory Evaluation, Consumer Preferences, Mixture Design

\section{Introduction}

Yam (Dioscorea spp.) is one of the most important sources of carbohydrates to many people and is considered a food security crop in West Africa [1,2]. Six major varieties of the starchy staple are cultivated for food uses in West Africa, with D. rotundata being the most valuable in market share $[3,4]$. Yam is preferred to other root and tuber crops and is the choice for festive occasions and performance of some activities of cultural significance [5]. Among root and tuber crops in Ghana, yam production and yield is only surpassed by cassava [6]. Yam is starchy and contains low amounts of proteins, fat and ash, ranging between 3.0-11.0\%, 0.05-2.5\% and 3.0-9.0\%, respectively for these three nutrients [7-9].

High postharvest losses of yams threaten its role as a food security crop and losses of $30-40 \%$ have been reported and attributed to spoilage due to sprouting, respiration, rot and mechanical damage $[3,10,11]$. This phenomenal occurrence is partly influenced among others by limited utilization avenues. Predominantly cultivated for culinary applications, food forms of yam consumed in Ghana is limited to boiled, fried, roasted or pounded variants [12-14]. The loss associated with the crop together with the need to diversify its uses calls for its conversion into other forms such as flours, to be used in a wide array of domestic and industrial applications.

Processing yams into flour is commonplace in some West African countries but largely remains unexplored in Ghana. Yam flour has the potential of serving as a primary ingredient in the production of bakery products, porridge, pudding and other meals. However, flours from yam as a starchy root tuber has inadequate amounts of proteins and fat $[7,9]$ and may provide only marginal nutrition to consumers, especially children. Studies have shown that flour from cereals and root tubers could be fortified with legumes and oilseeds to provide a complementary blend of essential nutrients for better nourishment $[15,16]$.

Legume seeds such as soybean (Glycine max) and cowpea (Vigna unguiculata) are rich in protein of high nutritional value and have been applied severally for fortifying foods with low 
protein concentration [17-19]. They contain slowly digestible starch, their protein is rich in lysine and they are considered a valuable source of dietary fiber [20]. Additionally, soybean contains about $20 \%$ oil on dry weight basis as well as isoflavones with numerous health benefits [21, 22],while cowpea is a major vegetable protein source containing 20-23\% crude protein and 50-67\% starch [23] and a good source of niacin, thiamine, riboflavin and other water-soluble vitamins. Further, cowpeas contain essential minerals such as calcium, magnesium, potassium, phosphorus and iron [20, 24, 25].

In Ghana porridge is mainly made from cereal flours. Fortification of yam flour with legumes for cooking porridge will help address protein-energy malnutrition especially in children and serve to better nourish consumers in vulnerable groups such as pregnant women and nursing mothers. As part of efforts to diversify the culinary uses of yam, the objective of this study was to develop yam flour fortified with starchy legumes (soybean and cowpea) and assess the sensory characteristics and consumer preferences of porridge made from fortified yam flour.

\section{Materials and Methods}

\subsection{Raw Materials}

Fully matured white yam (Dioscorea rotundata) variety (pona) was used together with soybean (Glycine max) and cowpea (Vigna unguiculata) to develop the fortified yam flour. These raw materials were procured from a source supplier at a local market (Haatso) in Accra and stored in a cool and dry place prior to its use for production of the flours.

\subsection{Flour Preparation}

Yam tubers were washed and hand-peeled. The peeled tubers were then sliced, rinsed in clean potable water and blanched at $90^{\circ} \mathrm{C}$ for $30 \mathrm{~min}$. The blanched yam slices were mashed and dried in a mechanical dryer (Apex Royce Rolls, London, UK) at $55^{\circ} \mathrm{C}$ for $12 \mathrm{hr}$. After drying, the yam chips were milled into flour using a disc attrition mill(Mill Machine, CSIR-FRI, Accra, Ghana).A motorized flour sifter (Flour Sifter, CSIR-FRI, Accra, Ghana) with a $250 \mu \mathrm{m}$ screen was used to remove fibers and larger particles to obtain fine flour with a uniform particle size. The flour was packaged in High Density Polyethylene (HDPE) bags, sealed and stored at $27 \pm 3{ }^{\circ} \mathrm{C}$ before use.

The soybean and cowpea were sorted to remove spoilt grains, stones and other foreign materials. The legumes were then washed, boiled for $30 \mathrm{~min}$, cooled and dried at $55^{\circ} \mathrm{C}$ for $12 \mathrm{hr}$ in a mechanical dryer. The dried soybean and cowpea were then milled separately with a laboratory disc attrition mill and sifted in a $250 \mu \mathrm{m}$ sieve. The flours were packaged in HDPE bags, sealed and stored at $27 \pm 3^{\circ} \mathrm{C}$ before use.

\subsection{Formulation of Yam-Legume Flour}

Yam flour and the flours from the legumes were combined in different proportions according to a 10 Design-Point formulation generated using Mixture Design (Minitab 16.2.3, MINITAB Inc., USA). The proportions of ingredients for the various formulations are shown in Table 1.

Table 1. Proportion of different flours in yam-legume flour formulations

\begin{tabular}{llll}
\hline \multirow{2}{*}{ Formulation } & \multicolumn{2}{l}{ Proportion of components (\%) } \\
& Yam flour & Soybean flour & Cowpea flour \\
\hline 1 & 60.0 & 20.0 & 20.0 \\
2 & 60.0 & 10.0 & 30.0 \\
3 & 73.3 & 13.3 & 13.3 \\
4 & 80.0 & 10.0 & 10.0 \\
5 & 66.6 & 16.6 & 16.6 \\
6 & 63.3 & 23.3 & 13.3 \\
7 & 70.0 & 10.0 & 20.0 \\
8 & 70.0 & 20.0 & 10.0 \\
9 & 60.0 & 30.0 & 10.0 \\
10 & 63.3 & 13.3 & 23.3 \\
\hline
\end{tabular}

\subsection{Preparation of Porridge from Yam-Legume Flour}

Each of the yam-legume formulations was reconstituted into a thick porridge with warm water $\left(45^{\circ} \mathrm{C}\right)$ and stirred to obtain a smooth consistency. The porridge was sweetened with table sugar and served to panelists while lukewarm $\left(38^{\circ} \mathrm{C}\right)$ into polypropylene containers with covers.

\subsection{Sensory Evaluation of Porridge from Yam-Legume Flour}

An acceptance test using a 7-point Hedonic scale with " 1 " representing dislike extremely and " 7 " representing like extremely was used for the sensory evaluation of the porridge prepared by the formulations [26, 27]. Twenty five trained panelists assessed the porridge. Each panelist evaluated 10 porridge samples at two sessions (5 samples per session), following a randomized order of presentation matrix (XLSTAT 2012, Statsoft, France).

Panelist were served $100 \mathrm{ml}$ of porridge in polypropylene containers with plastic spoons provided and instructed to taste and evaluate the samples on evaluation sheets. Sensory attributes assessed were colour and colour uniformity, mouthfeel, taste, aroma and overall acceptability. Panelists' general comments on samples were encouraged. The sensory evaluation was conducted in individual sensory booths in a sensory evaluation facility consistent with ISO 8589. Unsalted cracker and water were supplied to panelists for refreshing their palates before tasting subsequent samples.

Based on scores assigned to attributes evaluated, the 10 formulations were ranked ( $1=$ highest, $10=$ lowest $)$.

\subsection{Consumer Preferences Testing}

On the bases of the sensory evaluation outcome, two different formulations ( 3 and 4 ) were selected for consumer preferences testing. The flours were prepared into porridge and evaluated by sixty nine consumers. Participants were made up of $67 \%$ male and $33 \%$ females from diverse socio-economic backgrounds and were selected after reading and signing a consent form. Recruitment was based on interest and non-allergic to any of the ingredients used in the 
study. A 100 milliliters $(100 \mathrm{ml})$ of the porridge from the flour blends were presented to panelist in polypropylene cups, labeled with 3-digit code using randomized Design Matrix (XLSTAT 2012, Statsoft, France) [27, 28].An unsalted cracker and water were provided to clean and refresh the palate before evaluating subsequent samples. A 7-point Hedonic scale with " 1 " representing dislike extremely and "7" representing like extremely was used to assess preferences of the porridge from the flour formulations. Following the preferences testing, each consumer was also made to complete a questionnaire, consisting mainly of closed ended questions on consumer demography.

\subsection{Statistical Analysis}

The data of the sensory evaluation of porridge from yam-legume flour formulations was analyzed using Mixture Contour Plots (Minitab 16.2.3, MINITAB Inc., USA) to determine the most desirable formulations. Stepwise regression was used to determine the influence of sensory attributes on overall acceptability of the different formulations. Individual consumer preference scores from panelists were averaged and data analyzed using SPSS 17.0.1 [29].Statistical significance was set at a level of $95 \%$ confidence interval.

\section{Results and Discussions}

\subsection{Sensory Evaluation of Porridge from Yam-Legume Flour Formulations}

Panelists' rating of the porridge from the different flour formulation is presented in Table 2. The scores were generally low for all attributes of the products. Mouthfeel and taste received the lowest rating among the sensory attributes of the porridge. Porridge formulations with the lowest mouthfeel ratings were those that had high amounts $(30-40 \%)$ of legume flours while those with low proportions $(10-29 \%)$ of the legumes had the best taste. Also, porridge with fairly balanced and intermediary proportions of cowpea and soybean flour and a high amount (60-70\%) of yam flour had the highest overall acceptability. Highest scores for individual attributes and overall acceptability represents "like slightly" on the 7-point Hedonic scale. However, analysis of variance showed no significant differences $(p>$ 0.05 ) among the porridge formulations for all the attributes assessed, which is an indication that porridge from the various flour formulations were liked equally.

Table 2.Mean sensory scores of yam-legume flour formulations

\begin{tabular}{|c|c|c|c|c|c|c|}
\hline \multirow{2}{*}{ Formulation } & \multicolumn{5}{|c|}{ Mean score for attributes } & \multirow{2}{*}{ Mean Rank } \\
\hline & Colour & Aroma & Mouthfeel & Taste & Overall acceptability & \\
\hline 1 & $4.5 \pm 0.3^{\mathrm{a}}$ & $4.5 \pm 0.7^{\mathrm{a}}$ & $3.5 \pm 0.8^{\mathrm{ab}}$ & $3.8 \pm 0.6^{\mathrm{abc}}$ & $3.8 \pm 0.6^{\mathrm{a}}$ & $4.7 \pm 0.5^{\mathrm{ab}}$ \\
\hline 2 & $4.5 \pm 0.4^{\mathrm{a}}$ & $4.2 \pm 0.7^{\mathrm{a}}$ & $3.2 \pm 0.4^{\mathrm{a}}$ & $3.5 \pm 0.6^{\mathrm{abc}}$ & $3.3 \pm 0.5^{\mathrm{a}}$ & $6.8 \pm 0.8^{\mathrm{ab}}$ \\
\hline 3 & $4.5 \pm 0.6^{\mathrm{a}}$ & $4.5 \pm 0.6^{\mathrm{a}}$ & $4.3 \pm 0.4^{\mathrm{ab}}$ & $3.2 \pm 0.4^{\mathrm{ab}}$ & $4.2 \pm 0.5^{\mathrm{a}}$ & $4.3 \pm 0.6^{\mathrm{abc}}$ \\
\hline 4 & $4.8 \pm 0.6^{\mathrm{a}}$ & $4.8 \pm 0.8^{\mathrm{a}}$ & $5.0 \pm 0.7^{\mathrm{b}}$ & $4.8 \pm 0.6^{\mathrm{bc}}$ & $4.3 \pm 0.7^{\mathrm{a}}$ & $1.7 \pm 0.3^{\mathrm{c}}$ \\
\hline 5 & $3.5 \pm 0.6^{\mathrm{a}}$ & $3.8 \pm 0.3^{\mathrm{a}}$ & $3.5 \pm 0.3^{\mathrm{ab}}$ & $3.7 \pm 0.2^{\mathrm{abc}}$ & $3.3 \pm 0.2^{\mathrm{a}}$ & $8.3 \pm 0.4^{\mathrm{a}}$ \\
\hline 6 & $4.0 \pm 0.8^{\mathrm{a}}$ & $4.3 \pm 0.2^{\mathrm{a}}$ & $4.0 \pm 0.4^{\mathrm{ab}}$ & $4.2 \pm 0.5^{\mathrm{abc}}$ & $3.7 \pm 0.5^{\mathrm{a}}$ & $4.3 \pm 0.6^{\mathrm{ab}}$ \\
\hline 7 & $4.7 \pm 0.6^{\mathrm{a}}$ & $3.3 \pm 0.8^{\mathrm{a}}$ & $4.0 \pm 0.7^{\mathrm{ab}}$ & $2.8 \pm 0.9^{\mathrm{a}}$ & $3.3 \pm 0.8^{\mathrm{a}}$ & $6.3 \pm 0.8^{\mathrm{a}}$ \\
\hline 8 & $3.7 \pm 0.5^{\mathrm{a}}$ & $4.3 \pm 0.2^{\mathrm{a}}$ & $3.6 \pm 0.3^{\mathrm{ab}}$ & $5.2 \pm 0.3^{\mathrm{c}}$ & $5.2 \pm 0.3^{\mathrm{b}}$ & $5.0 \pm 0.7^{\mathrm{bc}}$ \\
\hline 9 & $3.3 \pm 0.4^{\mathrm{a}}$ & $4.2 \pm 0.6^{\mathrm{a}}$ & $3.7 \pm 0.4^{\mathrm{ab}}$ & $4.2 \pm 0.5^{\mathrm{abc}}$ & $3.8 \pm 0.3^{\mathrm{a}}$ & $6.8 \pm 0.5^{\mathrm{ab}}$ \\
\hline 10 & $4.5 \pm 0.8^{\mathrm{a}}$ & $4.0 \pm 0.7^{\mathrm{a}}$ & $3.7 \pm 0.6^{\mathrm{ab}}$ & $4.0 \pm 0.8^{\mathrm{abc}}$ & $4.0 \pm 0.7^{\mathrm{a}}$ & $6.3 \pm 0.3^{\mathrm{ab}}$ \\
\hline
\end{tabular}

$\dagger$ Means within the same column bearing the same superscripts are significantly different $(p<0.05)$

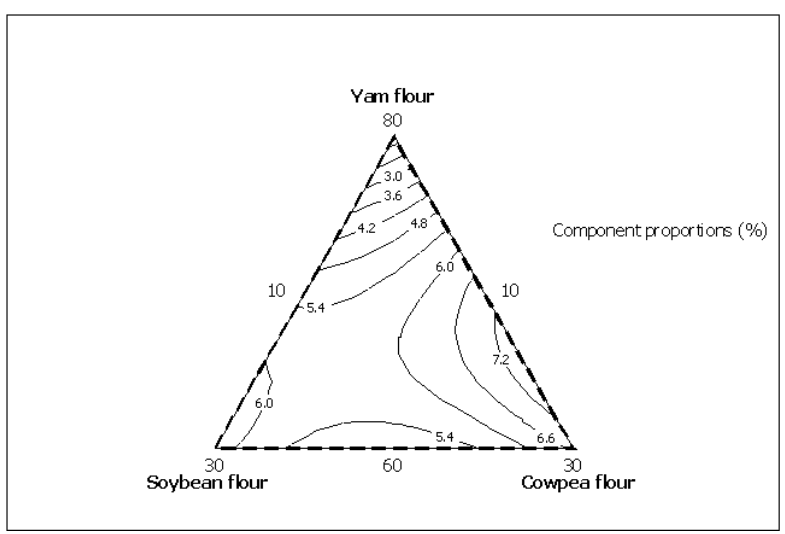

Figure 1.Effect of components on ranking of porridge

Sensory evaluation of the porridge showed that high proportion of yam in combination with low amounts (20.0-26.6\%) of both cowpea and soybean resulted in a highly ranked porridge formulation (Figure 1). This suggests that higher proportions of the legume flour in the blend reduced general preference for the porridge. The observation is likely to have resulted from a combination of reasons such as coarseness and beany flavour introduced by the flour from legumes, which affected mouthfeel and taste of the porridge. Although the legumes were parboiled, dried, milled and sieved, some extent of grittiness was perceived in the porridge because the particles of the legume flour must have been hard and irregularly shaped [30].Hard and irregular shaped particles are more easily detected in the mouth than softer and more rounded ones [30].

Beany flavour is related to lipoxygenases [31] and is undesirable and greatly reduces the acceptability of products containing cowpea and soybean [32]. Processing methods such as heat treatments, acid treatments, enzymatic treatments and addition of flavour compounds have been suggested to reduce the beany flavour [33, 34].Previous studies showed a reduction in acceptability of cowpea-fortified weaning foods as a result of the high cowpea inclusion levels because of the coarseness and beany 
flavour imparted by the cowpea $[35,36]$. Similar studies indicated that acceptability of bread fortified with soybean flour also reduced with increase in proportion of soybean $[37,38]$.

Stepwise linear regression (Table 3) conducted on the sensory revealed that taste was the only determinant of acceptability of the developed product. Among all the attributes, taste alone was observed to explain more than 70 $\%$ of the variation in acceptability of the porridge from the yam legume formulations. Although colour, mouthfeel and aroma have been cited as a determinant of consumer acceptability in other studies [39, 40], they were not significant predictors of porridge acceptability.

Table 3. Relationship between sensory attribute and overall likeness of formulations

\begin{tabular}{llll}
\hline Parameter & Acceptability estimates & SE of estimates & p-value \\
\hline Intercept & 1.489 & 0.777 & 0.092 \\
Taste & 0.742 & 0.194 & $0.014^{*}$ \\
\hline
\end{tabular}

* Significant at $p \leq 0.05 .{ }^{\dagger}$ Colour, aroma and mouthfeel were excluded from the model because they were not influential predictors of porridge acceptability.

\subsection{Consumer Preferences}

Sixty nine consumers took part in the consumer preferences testing of the two porridge formulations selected based on the outcome of the sensory evaluation. Majority $(66.7 \%)$ of the consumers was male and their median age group was 18-35 years (Table 4). The consumers were generally well educated and $90 \%$ had attained secondary education or better. Interestingly, $41 \%$ of them were actively engaged in skilled professions or unskilled labour. Student participants were $55 \%$ and only $4 \%$ were unemployed. Respondents $(70 \%)$ came from households of 4 or more members. The demographic characteristics of consumers was similar to that reported by Tortoe et al., [14] and Ghana Statistical Services [41].

Table 4. Demographic characteristics of participants

\begin{tabular}{lllll}
\hline Variable & Frequency & $\begin{array}{l}\text { Percentage } \\
(\%)\end{array}$ & $\chi^{2}$ & $p$-value \\
\hline $\begin{array}{l}\text { Gender } \\
\text { Male }\end{array}$ & 46 & 66.7 & 2.490 & 0.115 \\
Female & 23 & 33.3 & & \\
Age & & & & \\
$\begin{array}{l}\text { 18-35 } \\
36-45\end{array}$ & 62 & 89.9 & 0.440 & 0.803 \\
$46-55$ & 4 & 5.8 & & \\
$\begin{array}{l}\text { Educational level } \\
\text { Primary }\end{array}$ & 3 & 4.3 & & \\
Secondary & 1 & 1.4 & & \\
Tertiary & 52 & 23.2 & & \\
$\begin{array}{l}\text { Occupation } \\
\text { Skilled }\end{array}$ & & 75.4 & & \\
professional & 23 & 33.3 & & \\
Unskilled & 5 & 7.2 & & \\
$\begin{array}{l}\text { Student } \\
\text { Unemployed }\end{array}$ & 38 & 55.1 & & \\
\hline
\end{tabular}

Chi-square test showed no considerable differences among respondents with different demographic status for their preferred porridge formulation. This suggests that porridge from the fortified yam-legume would be acceptable by a wide range of consumers, probably as a breakfast meal. Observations from the consumer preference test validated the results of the sensory evaluation. The consumer panel also rated porridge from the two flour formulations similarly (Table 5), of a mean score for both formulations as "like very much" on the 7-point Hedonic scale. However, 71\% respondents selected porridge from the formulation that had a ratio of 8:1:1 for yam flour, soybean flour and cowpea flour.

Table 5. Mean score for porridge preference

\begin{tabular}{lllll}
\hline Formulation & Percentage & Mean score & Inference & t \\
\hline 4 & 70.8 & $6.0 \pm 0.6$ & Like very much & 1.063 \\
3 & 29.2 & $5.8 \pm 0.6$ & Like very much & \\
\hline
\end{tabular}

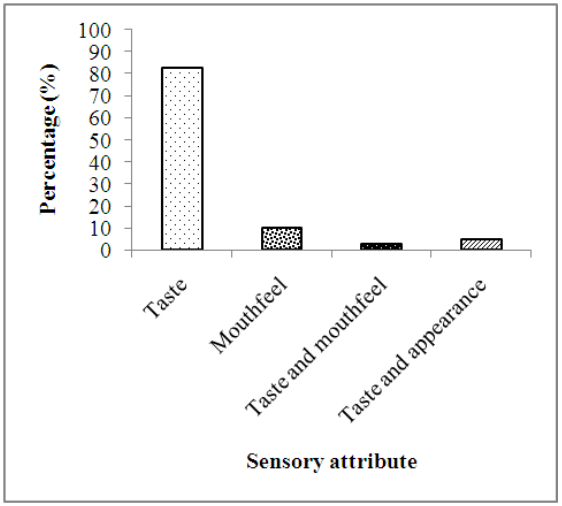

Figure 2. Influential attributes to consumers' preference

Similar to the results of the sensory evaluation, taste was observed to have an overwhelming impact $(p<0.0001$, $\left.\chi^{2}=43.550\right)$ on the selection of a preferred porridge formulation by the consumers. Further, mouthfeel and appearance influenced the choices made by the consumers, even though these properties did not have a significant role to play under the sensory evaluation (Figure 2). Colour and aroma, which less influenced the sensory evaluation were not mentioned by any of the consumers as a reason for selecting a preferred porridge formulation.

\section{Conclusion}

Sensory evaluation indicated that the panelists preferred formulations with high amounts of yam flour and minimal proportions of legumes flour. Among the sensory attributes evaluated only taste had a significant influence on porridge preferences. The consumer preferences test conducted on formulations 3 and 4 revealed an overwhelming consumer preferences for formulation 4, which contained yam flour, soybean flour and cowpea flour in a ratio of 8:1:1. 


\section{Acknowledgements}

The authors are grateful for the financial support from the Ministry of Agriculture and Fisheries of Japan and Mitsubishi Research Institute, Inc. Japan.

\section{References}

[1] Akissoe N, Joseph H, Christian M, Nago N2003. Effect of tuber storage and pre and post blanching treatments on the physicochemical and pasting properties of dry yam flour. Food Chem. 85, 1414-1419.

[2] Zannou A 2006.Socio-economic, agronomic and molecular analysis of yam and cowpea diversity in the Guinea-Sudan transition zone of Benin. PhD Thesis, Wageningen University.

[3] Bancroft RD 2000.Relieving post-harvest constraints and identifying opportunities for improving the marketing of fresh yam in Ghana, $1^{\text {st }}$ January- $31^{\text {st }}$ March, 2000. Final Project Report No: R6505. Natural Resources Institute, University of Greenwich, Chatham, Kent, UK. 51 pp.

[4] Otoo E, Asiedu R 2008. GGE biplot analysis of Dioscorea rotundata cultivar "Dente" in Ghana. Afr J Agric Res.3, 115-125.

[5] Osunde ZD2008. Minimizing Postharvest Losses in Yam (Dioscorea spp): Treatments and Techniques. In: Robertson GL, Lupien JR (eds.), Using food science and technology to improve nutrition and promote national development. International Union of Food Science and Technology, IUFoST.

[6] MoFA 2013.Agriculture in Ghana, Facts and Figures, Statistics Research and Information Directorate (SRID), Ministry of Food and Agriculture, Ghana.

[7] Afoakwa EO, Sefa-Dedeh S 2001. Chemical, compositional and quality changes occurring in Dioscorea dumetorum pax tubers after harvest. Food Chem. 75, 85-91.

[8] Shanthakumari S, Mohan VR, de Brittto J 2008.Nutritional evaluation and elimination of toxic principles in wild yam (Dioscorea spp.). Trop Subtrop Agrosys. 8, 319-325.

[9] Agbor-Egbe T, Treche S 1995. Evaluation of the chemical composition of Cameroonian yam germplasm. J Food Comp Ana. 8, 274-283.

[10] Dumont R 1995.The nature and importance of tuber damage during yam storage in Cote d'Ivoire: improvement development through research. Workshop on pests and pathogens of yams in storage. International Institute of Tropical Agriculture, Ibandan, Nigeria, Summary Document, 25 May 1995.

[11] Opara LU 1999.Yam Storage. In: Bakker-Arkema, FW (eds.), CIGR Handbook of Agricultural Engineering, Volume IV, Agro Processing. The American Society of Agricultural Engineers, Missouri, pp. 182-214.

[12] Oduro I, Ellis WO, Asamoah-Okyere DK, Adu-Amankwa P, Alemawor F, Amagloh FK 2007. Minimal processing of yam to increase consumers' acceptance. Proceedings of the $13^{\text {th }}$ ISTRC Symposium, pp. 473-477.

[13] Polycarp D, Afoakwa EO, Budu AS, Otoo E 2012.Characterization of chemical composition and anti-nutritional factors in seven species within the Ghanaian yam (Dioscorea spp.) germplasm. Int Food Res J.19, 985-992.

[14] Tortoe C, Nketia S, Owusu M, Akonor PT, Dowuona S, Otoo E2014. Sensory attributes and consumer preference of precooked vacuum-packaged yam from two cultivars of Ghanaian yam (Dioscorea rotundata) in the Accra Metropolitan Area. Advances Res. 2(1), 40-51.

[15] Eggleston G, Omoaka PE, Arowshegbe A 1993. Flour, starch and composite bread making quality of various cassava clones. JSci Food Agric. 62, 49-59.

[16] Boruch M 1985. Physico-chemical modification of potato starch with different grain size. Acta Aliment Poly.11, 43-51.

[17] Egounlety M 2002.Production of legume-fortified weaning foods. Food Res Int.35, 233-237.

[18] Nti CA, Plahar WA 1995. Chemical and biological characteristics of a West African weaning food supplemented with cowpea (Vigna unguiculata).Plant Foods Human Nutri. $48,45-54$.

[19] Sefah-Dedeh S, Cornelius B, Sakyi-Dawson E, Afoakwa EO 2003. Application of response surface methodology for studying the eating quality characteristics of cowpea-fortified nixtamalized maize. Innovat Food Sci Emerg Technol. 4,109-119.

[20] Phillips RD, McWatters KH, Chinnan MS, Hung YC, Beuchat LR, Sefa-Dedeh S, Sakyi-Dawson E, Ngoddy P, Nnanyelugo D, Enwere J, Komey NS, Liu K, Mensa-Wilmot, Y, Nnanna IA, Okeke C, Prinyawiwatkul W, Saalia FK 2003. Utilization of cowpeas for human food. Field Crops Res. $82,193-213$

[21] Ali AA, Velasquez MT, Hansen CT, Mohamed A, Bhathena SJ 2005. Modulation of carbohydrate metabolism and peptide hormones by soybean isoflavones and probiotics in obesity and diabetes. JNutriBiochem.16, 693-699.

[22] Song Y, Paik HY, Joung H 2008. Soybean and soy isoflavone intake indicate a positive change in bone mineral density for 2 years in young Korean women. Nutri Res. 28, 25-30.

[23] Quin FM 1997.Introduction: Advances in cowpea research. In: Singh BB, Mohan Raj DR, Dashiel KE, Jackai LEN (eds.) pp. ix-xv, Co-publication of International Institute of Tropical Agriculture, Ibadan, Nigeria.

[24] Philips RD, Mc Waters KH1991. Contribution of cowpeas to nutrition and health. Food Technol. 45 (9), 127-130.

[25] Abizari AR, Moretti D, Zimmermann MB, Armar-Klemesu M, Brouwer ID 2012. Whole cowpea meal fortified with NaFeEDTA reduces iron deficiency among Ghanaian school children in a malaria endemic area. The J Nutri 142, $1836-1842$.

[26] Stone H, Sidel JL 2004. Sensory Evaluation Practices, $3^{\text {rd }}$ Edition. Elsevier Academic Press, San Diego, California. pp. $247-277$.

[27] Hooda S, Jood S 2005.Organoleptic and nutritional evaluation of wheat biscuits supplemented with untreated and treated fenugreek flour. Food Chem. 427-435.

[28] Rampesad R, Badrie N, Comissiong E 2003.Physiochemical and sensory characteristics of flavored snacks from extruded cassava/pigeon pea flour. J Food Sci. 68, 363-367. 
[29] SPSS 2008.SPSS Statistics v. 17.0.1. SPSS Inc., Chicago III.

[30] Tyle P 1993. Effect of size, shape and hardness of particles in suspension on oral texture and palatability. Acta Psychol. $84,111-118$.

[31] Wang B, Xiong YL, Wang C2001. Physicochemical and sensory characteristics of flavored soymilk during refrigeration storage. J Food Qual. 24, 513-526.

[32] Bott L, Chambers E2006. Sensory characteristics of combinations of chemicals potentially associated with beany aroma in foods. JSen Stud. 21,308-321.

[33] Srinivas H, Swamylingappa B, Chand N1992. Secondary extraction of soybeans using hexane-acetic acid: effect on beany flavor removal and physicochemical properties. J. Agric Food Chem. 40,276-279.

[34] Maheshwari P, Murphy PA, Nikolov ZL 1997. Characterization and application of porcine liver aldehyde oxidase in the off-flavor reduction of soy proteins. J Agric Food Chem.45, 2488-2494.

[35] Adenuga W 2010.Nutritional and sensory profiles of sweet potato based infant weaning food fortified with cowpea and peanut. JFood Technol. 8, 223-228.
[36] Olapade AA, Oluwole OB,Aworh OC 2012. Physico-chemical properties and consumer acceptance of instant cowpea (Vigna unguiculata) powder for complementary food. Afr J Food Sci Technol.3, 102-106.

[37] Ivanovski B, Seetharaman K, Duizer LM 2012. Development of soy-based bread with acceptable sensory properties. J Food Sci. 71, 71-76.

[38] Natal DIG, Dantas MI, Vidigal MCT, Ribeiro SMR, Silva, RR, Martino HSD 2013. Physical and sensorial properties of potato bread fortified with whole soybean flour. Rev Clinical Nutri. 40,62-70.

[39] Folkenberg DM, Bredie WLP, MartensM 1999. Sensory-rheological relationships in instant hot cocoa drinks. J. Sen Stud.14, 181-195.

[40] Wrolstad RE, Smith DE 2010. Colour analysis, In: Nielsen, SS (ed.), Food Analysis, $4^{\text {th }}$ Edition. Springer Science and Business Media, New York. pp. 573-586.

[41] Ghana Statistical Services 2012. The 2010 population and housing census. Summary report of final results. Ghana Statistical Service. Accra, Ghana. 